\title{
First record of two Ganoderma species from North East Nile Delta- Egypt
}

\author{
El-Fallal $\mathrm{AA}^{1}$, El-Sayed $\mathrm{AKA}^{1}$ and El-Esseily $\mathrm{SR}^{1}$ \\ ${ }^{1}$ Botany Department, Faculty of Science, Damietta University, Damietta El-Gededa, PO 34517, Egypt.
}

El-Fallal AA, El-Sayed AKA, El-Esseily SR 2015 - First record of two Ganoderma species from North East Nile Delta-Egypt. Mycosphere 6(3), 248-259, Doi 10.5943/mycosphere/6/3/2

\begin{abstract}
Two Ganoderma species causing butt rot were collected and isolated from Ficus bengalensis tree at Mansoura and Citrus limon trees at Damietta, Egypt. The two species were identified, based on fruit bodies, culture characterization and taxonomic traditional methods. The DNA sequences analysis of the ribosomal 5.8S rRNA gene including the flanking internal transcribed spacers (ITS) was also performed to confirm their taxonomic position among the other Ganoderma species. The species status was confirmed as G. resinaceum EGM and Ganoderma sp EGDA. For conserving the two Ganoderma species, they were cultivated in sawdust bags of citrus, beech and spruce trees for the first time in Egypt. Primordial initiation and basidiocarp maturation were observed as the sequence of fruit body development in both species. The antler-like formation was only observed in Ganoderma sp EGDA.
\end{abstract}

Key words - Ganoderma - culturing - sawdust - phylogenetic tree - ITS DNA sequencing

\section{Introduction}

Ganoderma is a large widely distributed genus of the family Polyporaceae (Ganodermataceae), order Aphyllophorales, class Homobasidiomycetes, and division Basidiomycota (Chang 1995, Wasser \& Weis 1999). It possesses tough and leathery to woody basidiocarps termed polypore. They grow either as biotrophes on live trees, or necrotrophes on dead trees, logs and stumps. Ganoderma species can survive under hot and humid environments such as sub-tropical and tropical regions (Moncalvo \& Ryvarden 1998). The most species of Ganoderma are white-rot fungi with the ability to decay lignin as well as cellulose (Adaskaveg \& Gilbertson 1994). They are responsible for wood-decaying of conifers and hardwoods occurring throughout the world. Root and stem rot caused by Ganoderma species result in worldwide losses of several crops and trees (Martinez et al. 1994, Miller et al. 1995). On the other side, intensive studies showed that different bioactive components of Ganoderma have several medicinal effects, such as alkaloids, terpenoids, polysaccharides, steroids, fatty acids, and proteins (Mizuno et al. 1995, Russel \& Paterson 2006, Ihayere et al. 2010). These compounds have immune-modulating, hypoglycemic, antimicrobial, antitumor, cardiovascular and other therapeutic effects (Lin et al. 1995, Park et al. 1997, Lee et al. 1998, Wasser \& Weis 1999, Gao et al. 2005, Jiang et al. 2005, Ofodile et al. 2005).

Morphological character variability often imposes difficulties in the identification of Ganoderma species (Ryvarden 1985, Moncalvo \& Ryvarden 1997). The plurality of criteria 
employed by different taxonomists, together with lost type specimens and the absence of modern descriptions, has over the years led to great confusion, making the taxonomy of this group very difficult. Due to this confusion it was proposed that molecular tools could be established to confirm identification (Buchanan \& Wilke, 1995, Moncalvo et al. 1995a). However, an accurate identification system for Ganoderma taxa should be based on traditional classification together with the development of genetic markers for individual strains or species. A variety of molecularbased techniques have been used to study genetic diversity in Ganoderma, such as analysis of isozymes (Lan et al. 1998), Restriction Fragment Length Polymorphism (RFLP) (Toyomasu et al. 1992, Park \& Ryu 1996), random amplified polymorphism DNA (RAPD) (Wang et al. 2003), amplified fragment length polymorphism (AFLP) (Qi et al. 2003), internal transcribed spacers (ITS) DNA sequencing technique (Moncalvo et al. 1995a,b, Sokol et al. 1999, Arulpandi \& Kalaichelvan 2013).

In the present study, two Ganoderma species are described for the first time from North East Delta Egypt. They were identified based on internal transcribed spacer analysis as well as morphological (both microscopically and macroscopically) characteristics. They had been conserved by isolation and cultivation.

\section{Materials \& Methods}

\section{Isolates collections and preparation}

Fruiting bodies of Ganoderma species were collected from living infected Ficus bengalensis tree at Mansoura University campus, Mansoura governorate, Egypt (giving EGM as a strain name) and from living Citrus limon tree in farm at Damietta governorate, Egypt (giving EGDA as a strain name).

Isolation of mycelium was done from fresh and cleaned basidiocarps. Small pieces of basidiocarps were cut and surface sterilized with 5\% sodium hypochloride for $2 \mathrm{~min}$, and then plated onto potato dextrose agar (PDA) medium supplied with traces of Streptomycin sulphate. The developed pure mycelia were subcultured and maintained on PDA slants. The fungal identification was performed according to the taxonomic keys and descriptions were consulted (Ryvarden 2000, Foroutan \& Vaidya 2007, Bhosle et al. 2010).

Descriptions of basidiomes were made according to their external and internal morphology. For external morphology the material was observed for colour, texture, type of attachment to the host, pore morphology, tubes thickness, margin, hymenial, and pileal surface of basidiocarp. For internal morphology, thin, hand sections were taken from fruiting body passing through cutis, context and from the tube layer of each sample respectively and mounted in $10 \% \mathrm{KOH}$ and also in Melzer's reagent (Beneke 1958).

The slides were observed under Optika B-350 compound microscope having a combination of 10x eyepiece and 10x, 45x and oil immersion (i.e., 100x), objectives. Photographs were taken using Canon digital camera. Measurements of hyphae, cutis element etc, were taken using objective micrometer or calibrated ocular.

\section{Culture study}

Isolates were grown on malt extract agar (MEA) medium at $30 \pm 1^{\circ} \mathrm{C}$ for 7 days for cultural study. They were examined after 3 days incubation for chlamydospore and primordia formation and culture reverse color. Growth rate of isolates was measured every day.

\section{Mycelial growth of Ganoderma species on different types of sawdust}

Sawdust from three different trees including citrus tree (Citrus limon) from citrus farm, beech tree (Fagus sp.) and spruce tree (Picea abies) from carpentry workshops were prepared as a major component in the basal substrate by mixing with $5 \%$ wheat bran, $0.2 \%$ magnesium sulphate and $1 \%$ calcium sulphate. Each sawdust mixture was put in $10 \mathrm{~cm}$ Petri dishes $(3 \mathrm{gm} / \mathrm{plate})$. After sterilization, $20 \mathrm{ml}$. of molten agar were poured on the top and inoculation was done later. The 
mycelial growth was recorded as a colony diameter. The kind of sawdust which provided good mycelial growth of both Ganoderma species was selected for cultivation.

\section{Mushroom cultivation}

Spawn preparation - 100gm sorghum gains were placed in glass jars and mixed with $3 \%$ of a mixture of calcium sulphat and calcium carbonate in ratio 4:1 with adding $50 \mathrm{ml}$ water then autoclaved for $30 \mathrm{~min}$ at 15 p.s.i. After cooling five agar discs from fully grown PDA cultures were used for inoculation the spawn medium. Incubation was carried out at $30^{\circ} \mathrm{C}$ for 10 days (El-Fallal 1990).

Substrate preparation - 400gm of selected sawdust was mixed with wheat bran, magnesium sulphate and calcium sulphate as 5\%, 0.2\%, and 1\% respectively (Triratana et al. 1991). Polypropylene bags of the size 8.5" x 15 " were filed two third with mixture to leave air space for ventilation (Chen 2004). Humidity was adjusted to 55\%. Through a plastic neck the free end of the bag was pulled up tightly, and then the edges were pulled down. They were covered with cotton plugs and autoclaved at 15 p.s.i for 30 min daily for four consecutive days.

Spawning and spawn running - After cooling they were inoculated with 5\% sorghum grain spawn by localized spawning technique (Chen 2004). The bags were incubated in incubator at $30^{\circ} \mathrm{C}$ for 10-15 day until the mycelia colonized the substrate. Then they are transferred to a mushroom house at ambient temperature $\left(27^{\circ} \mathrm{C}-30^{\circ} \mathrm{C}\right)$. The bags were kept for a week or more for maturation of the culture blocks when dense and leathery yellowish white mycelia could be observed.

Harvesting - The plugs necks were removed and the bags were placed on shelves and totally covered with a plastic sheet. After the primordia appeared, the fruiting bodies were harvested at the time that the color of the cap was uniform.

The number of primordia and fruiting bodies were determined. The fresh and dry weights of the fruiting bodies were determined. The yield and the biological efficiency (B.E.) were determined by the ratio of fresh weight of fruiting bodies per dry weight of substrate expressed in percentage. The mushrooms were died three times in an oven at $60^{\circ} \mathrm{C}$ for 8 hours.

\section{DNA extraction}

Genomic DNA was extracted according to the procedure of Lee \& Taylor (1990) with some modifications. Fresh mycelia were collected from $10^{\text {th }}$ day old culture on PDA medium and were frozen with liquid nitrogen followed by grinding with sterilized sonicator. Then $500 \mu 1$ extraction buffer (Equal volume of 50mM Tris- $\mathrm{HCl}$ (PH 7.5), 50mM EDTA (PH 8.0) and 1\% SDS (Sodium dodecyl sulphate) was added to the micro tube sample and incubated at $65^{\circ} \mathrm{C}$ for $30 \mathrm{~min}$. After incubation the same volume of ( 25 Phenol: 24 Chloroform: 1 Isoamyl-alcohol) mixture was added, mixed by inverting the tubes and centrifuged at $4^{\circ} \mathrm{C}$ for $10 \mathrm{~min}$ at $12000 \mathrm{rpm}$.

\section{PCR amplification and sequencing of ITS-5.8S rRNA region}

The oligonucleotide primers used for amplification and sequencing of the ITS regions including 5.8S rRNA were those described by White et al. (1990). The primers ITS4 $\left({ }^{5}\right.$ TCCTCCGCTTATTGATATGC $\left.{ }^{3}\right)$ and ITS5 ( ${ }^{5}$ GGAAGTAAAAGTCGTAACAAGG $\left.{ }^{3 \prime}\right)$ were made by BiONEER.

The PCR mixture consisted of $4 \mu \mathrm{l}$ of each primer (20 Pico mole $\mathrm{ml}^{-1}$ ), $1 \mu \mathrm{l}$ of chromosomal DNA and $25 \mu 1$ Dream Taq (Thermo scientific- Green PCR Master Mix) to a final volume of 50 $\mu 1$. PCR was performed using a thermal cycler (TECHENE model FTC3102, UK) with initial denaturation at $94^{\circ} \mathrm{C}$ for $5 \mathrm{~min}$, followed by 35 cycles at $94^{\circ} \mathrm{C}$ for $1 \mathrm{~min}, 55^{\circ} \mathrm{C}$ for $1 \mathrm{~min}$ and $72^{\circ} \mathrm{C}$ for $2 \mathrm{~min}$, then final extension at $72^{\circ} \mathrm{C}$ for $10 \mathrm{~min}$.

\section{Alignment and phylogenetic analysis}

BLAST (Altschul et al. 1990, 1997) was performed for the obtained ITS DNA sequence to match the best similarities with other related ITSs on database. The best DNA sequence similarities with our ITS region were obtained from NCBI GenBank and aligned using CLUSTAL W 
(Thompson et al. 1994). Unalignable regions were excluded manually and the sequences from the same species and unidentified organisms were discarded. Finally, Phylogenetic tree viewing and analyses were conducted using MEGA version 4 (Tamura et al. 2007).

\section{Statistical analysis}

The data were analyzed by using the analysis of variance (ANOVA) and mean separation was done by Duncan Multiple Range Test (DMR) using the SPSS version 22 program.

\section{Results}

\section{Morphological character}

The basidiocarp of G. resinaceum EGM strain is perennial, stipitate with a short and round expanding liver brown stip ( $5 \mathrm{~cm}$ length and $1.5-2.5 \mathrm{~cm}$ thick), which is lateral, broadly attached. Furthermore, the basidiocarp (10.0-11.5 x 16-17.5 x 1.3-2.0cm) is corky to woody, slightly bent and eccentric. The basidiocarp upper surface is laccate, bay to wine, thick, slightly zonate, sulcate, and glabrous when fresh, often covered with cinnamon powder of deposited basidiospore (Fig. 1.A) .The surface of young basidiocarp is shiny, by getting older, it becomes dull as a result of resinous layer excretion which becomes yellowish when crushed and melt in a match flame. The basidiocarp margin $(0.4-1.3 \mathrm{~cm})$ is rounded and light ochraceous to buff in colour at early stage, which then it turned brown later. Pore surface is creamy at first then turned pale brown at maturity (Fig. 1.B). Pores (3-4 per $\mathrm{mm}$ ) are irregular angular pentagonal or hexagonal with $117-317 \mu \mathrm{m}$ diameter. Tube $(0.3-1.1 \mathrm{~cm})$ is brown and context $(0.3-1.0 \mathrm{~cm})$ is light brown (Fig. 1.C). Cutis formed by claviform hyphae 10 x $20 \mu \mathrm{m}$ (Fig. 1.D). Hyphal system is dimitic, generative hyphae thin with clamp connection. Skeletal hyphae are aseptate thick walled, branched, yellowish brown. Cuticle cells are club shaped, smooth, opicaly faintly amyloid. Basidiospores (6 x 9-10 $\mu \mathrm{m})$ are oblong, ellipsoid, truncate, yellowish brown, semirugose with thick epispore (Fig. 1.E).
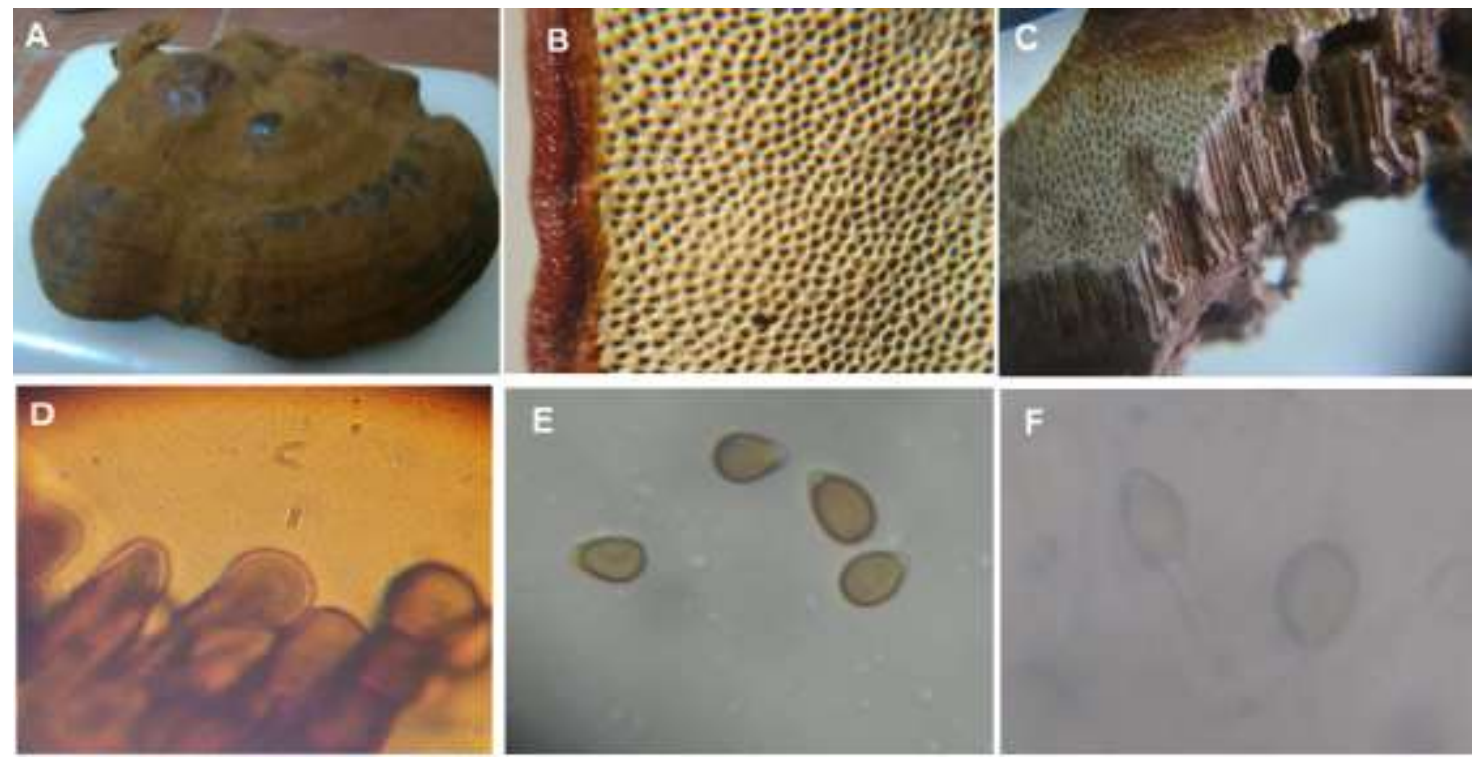

Fig. 1 - Fruit body external and internal morphology of wild G. resinaceum EGM. The upper surface of basidiocarp (A), the lower pore surface and margin of basidiocarp (B), tube layer and context (C), claviform hyphal cutis (D), basidiospors (E) and lemon shape chlamydospores (F)

Ganoderma sp. EGDA isolate possessed a basidiocarp which is annual, stipitate with long, lateral, reddish brown expanding stipe (3-10 cm length and $1-3 \mathrm{~cm}$ thick). One stalked fruiting body is found growing from a single attachment to lemon tree; however mostly two fruiting bodies can grow from one base (Fig. 2.A). The basidiocarp $(2.5-3 \times 4.5-6 \times 1.0 \mathrm{~cm})$ is corky to woody at first irregularly knobby or elongated but by maturity fan shaped. The basidiocarp upper surface is 
laccate, distinct varnished shinny appearance reddish brown to mahogany when mature. When it is young, it is often with zones of bright yellow and white toward the margin. The basidiocarp margin firstly white turned into yellow. Pore surface is white creamy. Pores (4-6 per mm) are irregular circular to oval with $133-166.5 \mu \mathrm{m}$ diameter (Fig. 2.B). Tubes $(0.1-0.5 \mathrm{~mm}$ ) are usually brown and context $(0.25-0.5 \mathrm{~mm})$ colour is tan to pale brown (Fig. 2.C). Cutis is formed by claviform hyphae $(10 \times 25-27 \mu \mathrm{m})$, which are sometimes divided into two (Fig. 2.D). Hyphal system is trimitic, generative hyphae thin walled, hyaline with clamp connection. Skeletal hyphae are long, not branched, and thick walled. Binding hyphae are thick walled, tremendously and frequently branched. Basidiospores (13-15 x 20-27 $\mu \mathrm{m})$ are ovoid, ellipsoid, truncate, dark brown, fuscous, and ornamented with thick epispore (Fig. 2.E).
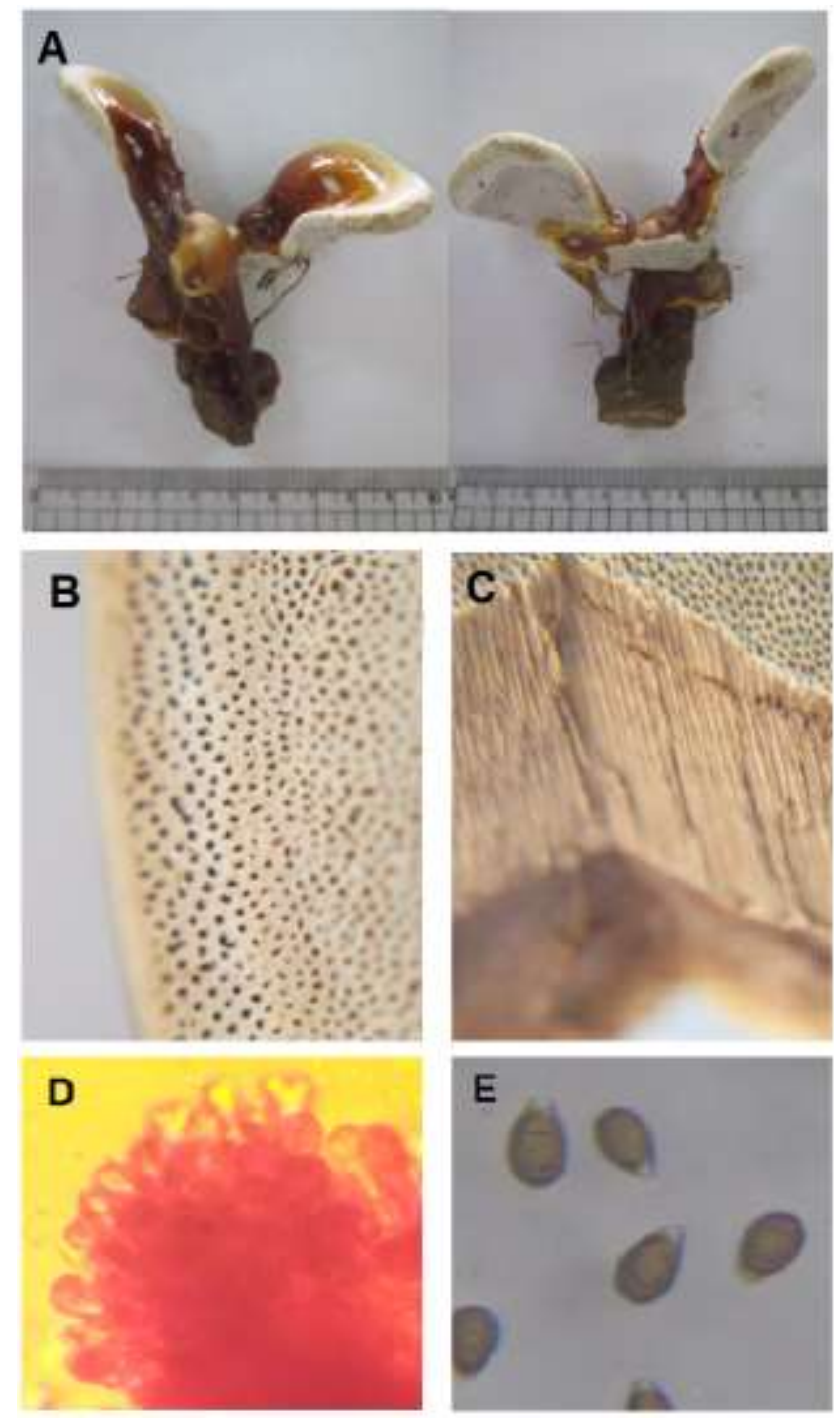

Fig. 2 - Fruit body external and internal morphology of wild Ganoderma sp EGDA. The dorsal and ventral view of two fruiting bodies originate from one base (A), the lower pore surface and margin of basidiocarp (B), tube layer and context (C), the cutis (D), basidiospores (E)

\section{Cultural characteristics}

The growth rate of $G$. resinaceum EGM mycelia was $1.7-2.1 \mathrm{~cm} /$ day. Mycelial mat was white at first. Latter, it turned cream coloured with a few light yellowish zones. Hyphae are hyaline, thin-walled and branched. Oxalics are usually found. Texture of mycelia mat is faint during first day. Later on the whole surface becomes much denser. Chlamydospores (8.33-13.32 × 10.0$16.65 \mu \mathrm{m}$ ) were lemon shaped, terminal, rarely intercalary, thick-walled and golden color (Fig. 1.F). Primordia were formed within 9-12 day after exposure to light. 
Ganoderma sp EGDA growth rate was $1.6-1.9 \mathrm{~cm} /$ day. Early growth of mycelia was white, then turned to cream coloured with a few light brownish zones and reversed brown color after 1012 days. Hyphae are hyaline, thin-walled, branched and aseptate. Oxalics are densely found. Texture of mycelia mat is farinaceous with scattered dots later whole surface becoming leathery farinaceous and much denser. Chlamydospores are absent.

\section{Molecular identification}

The PCR product sequencing of the ITSI-5.8S-ITSII rDNA region revealed $660 \mathrm{bp}$ for both G. resinaceum EGM and Ganoderma sp. EGDA, which were submitted in the GenBank with accession numbers LN774970 and LN774971, respectively. The DNA sequence The DNA sequence alignment of the ITS region for G. resinaceum EGM showed the highest identity (99\%) with other different $G$. resinaceum strains on database. Also, it showed $99 \%$ identity with $G$. pfeifferi G2/11 isolate, and 98\% with G. lucidum ATCC64251 isolate. The phylogenetic tree based on ITS DNA sequence (Fig. 3) clustered G. resinaceum EGM in one clade with some other isolates of the same $G$. resinaceum species possessing 0.00476 dissimilarity distance with $G$. lucidum ATCC64251 strain.

The DNA sequence alignment of ITS region for Ganoderma sp EGDA exhibited the highest similarities reached to $94-95 \%$ with many different strains of $G$. applanatum and other different species like G. cupreum GanoTK4, G. cupreum SUT-H1, G. mastoporum GDGM2572, G. oregonense ASI7063, G. pfeifferi GPF1, G. pfeifferi GPF2, G. lucidum BCRC36123 and many other Ganoderma species as described in the phylogenetic tree (Fig. 3). The phylogenetic tree separates Ganoderma sp EGDA, G. cupreum GanoTK4, G. cupreum SUT-H1 and G. mastoporum GDGM2572 in one group with dissimilarity distance reached 0.02408 .

\section{Mycelial growth of Ganoderma species on different types of sawdust}

The mycelial growth on sawdust-agar media indicated that beech sawdust was the best when compared with the two other kinds (Table 1). Although both beech and lemon sawdust were not significantly different, beech sawdust was used because it is popular as a local industrial wastes.

Table 1 Effect of different sawdust type on the growth of the two species of Ganoderma after 6 days.

\begin{tabular}{ccc}
\hline Sawdust types & Growth $(\mathbf{c m})$ & \\
& G. resinaceum EGM & Ganoderma sp EGDA \\
\hline Citrus & $7.8 \pm 0.000^{\mathrm{a}}$ & $6.8 \pm 0.058^{\mathrm{a}}$ \\
Beech & $8.8 \pm 0.088^{\mathrm{b}}$ & $7.0 \pm 0.000^{\mathrm{b}}$ \\
Spruce & $3.0 \pm 0.067^{\mathrm{c}}$ & $1.8 \pm 0.033^{\mathrm{c}}$ \\
\hline
\end{tabular}

Means with different letters within a column are significantly different $(\mathrm{P}<0.05)$

\section{Mushroom cultivation}

Generally, G. resinaceum EGM produced primordia and fruiting bodies faster than Ganoderma sp EGDA. G. resinaceum EGM required two months, whereas Ganoderma sp EGDA needs three months to produce fruiting bodies after inoculation (Table 2). The average number of primordial and fruiting bodies produced were presented in Table 3. The two Ganoderma species produced almost the same number of primordia and also the percentages development of primordia to fruiting bodies. The quality of fruiting body was expressed as fresh weight, dry weight and diameter. Table 4 shows that Ganoderma sp EGDA has better quality in term of dry and fresh weight than $G$. resinaceum EGM. Furthermore, the cultivation of $G$. resinaceum EGM exhibited perennial basidiocarp formation as two successive tube layers (Fig. 4). In case of Ganoderma sp EGDA cultivation, some primordial elongated perpendicularly into antler-like structure (Fig. 5), which thereafter began to expand horizontally giving rise to undeveloped pila. 


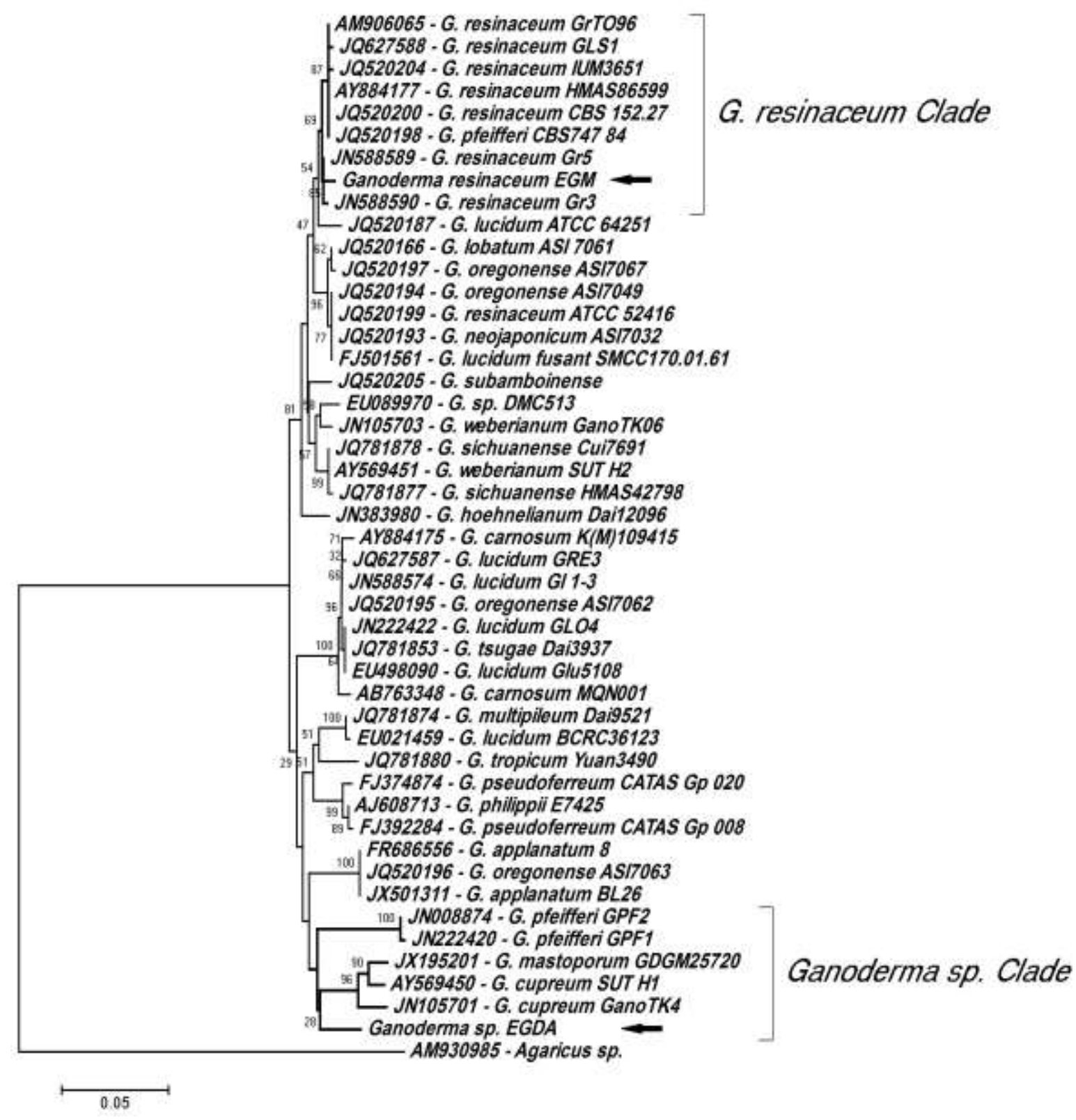

Fig. 3 - Phylogenetic tree analysis based on the ITS1-5.8S-ITS2rDNA sequence alignment for $G$. resinaceum EGM (AC:LN774970) and Ganoderma sp EGDA (AC:LN774971) with some other related Ganoderma species which possessed the best similarity. The ITS sequence of Agaricus sp (AC:AM930985) was used as outgroup to root the tree. The neighbor-joining was performed using the maximum composite likelihood methods (Tamura and Nei, 1993). The values next to branches are confidence levels estimated by 1000 bootstrap replicates. The values below 25 was excludes.

Table 2 The average time required for primordial development and fruit body production of the two Ganoderma strains.

\begin{tabular}{ccc}
\hline Ganoderma strain & $\begin{array}{c}\text { Primordial development } \\
\text { (Days after inoculation) }\end{array}$ & $\begin{array}{c}\text { Fruiting body production } \\
\text { (Days after primordial developed) }\end{array}$ \\
\hline G. resinaceum EGM & $29.57 \pm 0.369^{\mathrm{a}}$ & $59.71 \pm 0.286^{\mathrm{a}}$ \\
Ganoderma sp EGDA & $44.43 \pm 0.369^{\mathrm{b}}$ & $89.86 \pm 0.404^{\mathrm{b}}$ \\
\hline
\end{tabular}

Means with different letters within a column are significantly different $(\mathrm{P}<0.05)$ 
Table 3 The average number of fungal primordium and fruiting body produced by the two Ganoderma strains

\begin{tabular}{cccc}
\hline Ganoderma strain & $\begin{array}{c}\text { Number of } \\
\text { primordium }\end{array}$ & $\begin{array}{c}\text { Number of } \\
\text { fruiting bodies }\end{array}$ & $\begin{array}{c}\text { \% of primordium developed to } \\
\text { fruiting bodies }\end{array}$ \\
\hline G. resinaceum EGM & $9.86 \pm 0.670^{\mathrm{a}}$ & $2.14 \pm 0.261^{\mathrm{a}}$ & $21.99 \pm 3.050^{\mathrm{a}}$ \\
Ganoderma s EGDA & $8.43 \pm 0.841^{\mathrm{ab}}$ & $1.57 \pm 0.202^{\mathrm{ab}}$ & $18.51 \pm 1.195^{\mathrm{ab}}$ \\
\hline
\end{tabular}

Means with different letters within a column are significantly different $(\mathrm{P}<0.05)$

Table 4 Quality of fruiting body produced by the two Ganoderma strains.

\begin{tabular}{ccccc}
\hline Ganoderma strain & $\begin{array}{c}\text { Fresh weight } \\
\text { average of } \\
\text { individual fruiting } \\
\text { body }(\mathbf{g})\end{array}$ & $\begin{array}{c}\text { Dry weight } \\
\text { average of } \\
\text { individual fruiting } \\
\text { body }(\mathbf{g})\end{array}$ & $\begin{array}{c}\text { Diameter } \\
\text { average of } \\
\text { individual } \\
\text { fruiting body } \\
\text { (cm) }\end{array}$ & $\begin{array}{c}\text { The biological } \\
\text { efficiency } \\
\text { (B.E.) \% }\end{array}$ \\
\hline G. resinaceum EGM & $14.92 \pm 3.223^{\mathrm{a}}$ & $12.62 \pm 3.050^{\mathrm{a}}$ & $7.1 \pm 0.245^{\mathrm{a}}$ & $3.7 \pm 0.806^{\mathrm{a}}$ \\
Ganoderma $\mathrm{sp}$ EGDA & $16.79 \pm 2.772^{\mathrm{ab}}$ & $14.49 \pm 2.772^{\mathrm{ab}}$ & $8.5 \pm 0.165^{\mathrm{b}}$ & $4.2 \pm 0.693^{\mathrm{ab}}$ \\
\hline
\end{tabular}

Means with different letters within a column are significantly different $(\mathrm{P}<0.05)$
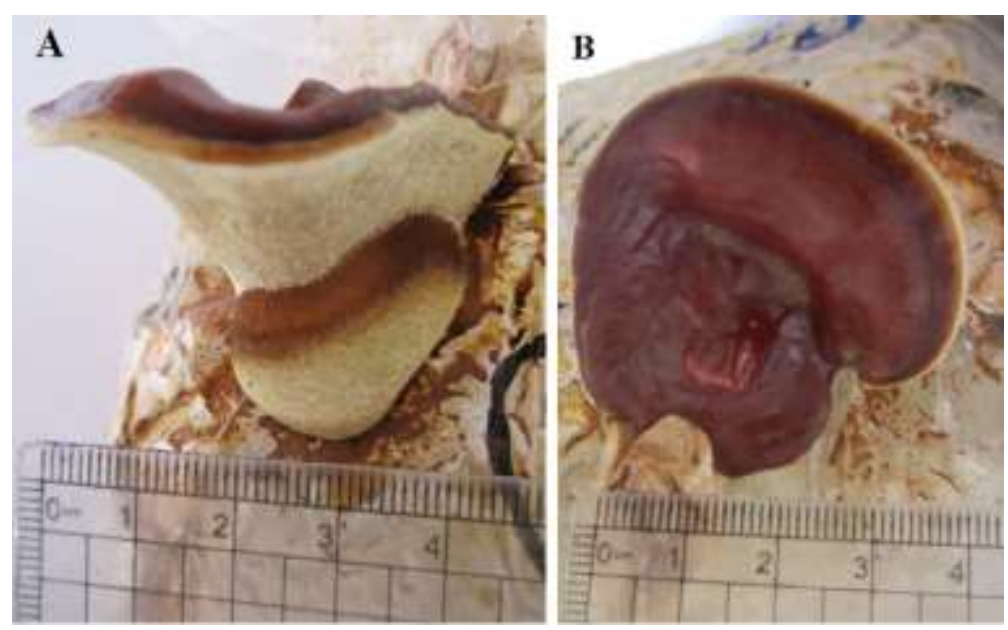

Fig. 4 - Fruit body development of G. resinaceum EGM showing two tube layer (perennial) lateral view (A), and upper surface of basidiocarp (B).
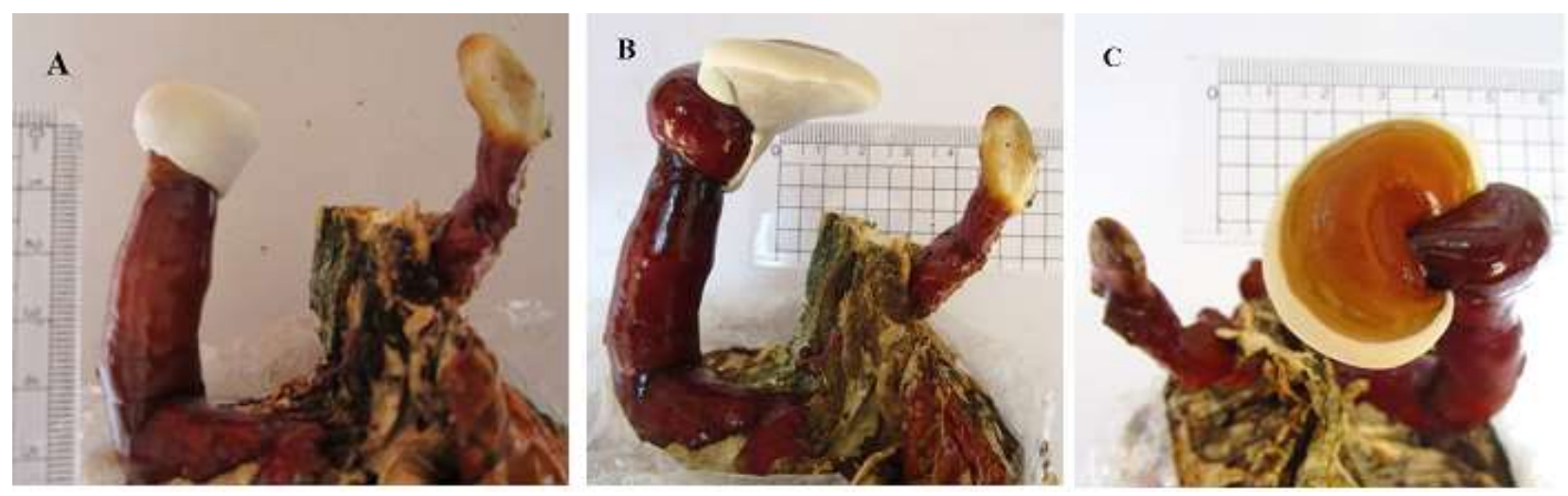

Fig. 5 - Sequence of fruit body development of Ganoderma sp EGDA showing antler-like formation. The formation of fruiting body after about 21 days (A), 42 days (B) and 63 days (C) of primordial development. 


\section{Discussion}

This study represents two Ganoderma species recorded for the first time in North East Delta region of Egypt. G. resinaceum has been previously recorded by Mahmoud et al. (2007) in Gharbia Governorate (North West Delta-Egypt), but they neither mentioned the exact host on which the fruiting bodies grew nor any description of the fruiting body. Our strains identification was based on both morphological observations and DNA sequence analyses of ITS region. The Ganoderma isolate found growing on ficus trees $(G$. resinaceum EGM) was morphologically similar to other resinaceum species (Ryvarden 2000), with some variations in basidiocarps dimensions of strains identified by Bhosle et al. (2010) and Mohanty et al. (2011). However, growth rate of $G$. resinaceum EGM was higher than that described by Mohanty et al. (2011). On the other hand, the ITS sequence alignment of $G$. resinaceum EGM confirmed its identification as it showed high similarities reached $99 \%$ with other $G$. resinaceum strains on database.

The isolated Ganoderma strain from lemon tree showed indefinite morphological character towards a precise Ganoderma species. It possessed some morphological character resembling $G$. tsugae and G. lucidum complex such as antler-like shape during the basidiocarp development, laccate varnished shinny basidiocarp which is at first irregularly knobby or elongated but by maturity becomes fan shaped. Also they have long, lateral and reddish brown stipe (Nanthini 2010). However, it differs from G. tsugae and G. lucidum complex as it has no dimitic hyphal system, hemlock varnish shelf appearance and yellowish reverse colour. Furthermore, the culture character like growth rate of G. tsugae is much slower (Nobles 1948) than Ganoderma sp EGDA. Based on ITS DNA sequence, the phylogenetic tree clustered Ganoderma $s p$ EGDA in one diverse clade included some strains of G. cupreum, G. mastoporum, and G. pfeifferi which are morphologically different from it (Foroutan \& Vaidya, 2007, Arulpandi \& Kalaichelvan, 2013).

The highly polymorphism of Ganoderma strains may relate with their complex growing environments and genetic background (Lin 2001), that make it difficult to give precise identification at some species or variety level. So, we may assume that Ganoderma sp EGDA isolated from lemon tree could be considered a new species depending on, not only its variable morphological characters, but also molecular criteria of ITS sequence.

Fruiting bodies formation is initiated by mycelial growth, followed by the production of primordia (Alexopoulos et al. 1996). The cultivation of Ganoderma is firstly introduced to Egypt in this present study in our mushroom unit (Faculty of Science, Damietta University). Little literatures were concerned about $G$. resinaceum cultivation (Hafiz et al. 2007). They obtained production rate of $G$. resinaceum similar to our results of $G$. resinaceum EGM. The period taken to complete the life cycle from primordial formation to fruiting bodies maturation of Ganoderma sp EGDA are approximately the same with G. lucidum (Rajapakse et al. 2013). The development percentage of fruiting bodies from primordia, however, was lower than that obtained with G. lucidum isolates (Sukarno et al. 2004). The biological efficiency obtained from this study was quite similar to the other works (Hafiz et al. 2007, Magday et al. 2014).

With the significant findings obtained from the present study, the discovery of new Ganoderma sp EGDA growing on lemon tree causing butt rot and a new strain of G. resinaceum EGM causing butt rot of ficus tree. They can be cultivated in local agro-industrial residues and are considered as a promising contribution to the records of successfully domesticated wild nutraceutical mushrooms in Egypt.

\section{References}

Adaskaveg J, Gilbertson R. 1994 - Wood decay caused by Ganoderma species in the G. lucidum complex. In: Ganoderma - systematics, Phytopathology and Pharmacology. Buchanan, P.K.; Hseu, R.S. \& Moncalvo, J.M. (eds). Proceedings of contributed symposium 59A, B, The 5th International Mycological Congress. Vancouver, pp.79-93.

Alexopoulos CJ, Mims CW, Balckwell M. 1996 - Introductory mycology. John Wily \& Sons, Inc, New York. 
Altschul SF, Gish W, Miller W, Myers EW, Lipman DJ. 1990 - Basic local alignment search tool. J. Mol. Biol. 215, 403-410.

Altschul SF, Madden TL, Schaffer AA, Zhang J, Zhang Z, Miller, W, Lipman DJ. 1997 - Gapped BLAST and PSI-BLAST: A new generation of protein database search programs. Nucleic Acids Research 25(17), 3389-3402.

Arulpandi I, Kalaichelvan PT. 2013 - Ganoderma adspersum and Ganoderma cupreum from South India, First report based on molecular phylogeny. Int. J. Curr. Microbiol. App. Sci. 2, 693702.

Beneke ES. 1958 - Laboratory Manual of Medical Mycology. 86, 1-13.

Bhosle S, Ranadive K, Bapat G, Garad S, Deshpande G, Vaidya J. 2010 - Taxonomy and diversity of Ganoderma from the western parts of Maharashtra (India). Mycosphere 1, 249-262.

Buchanan PK, Wilke JP. 1995 - Taxonomy of New Zealand Ganoderma two non lacate species. In: Ganoderma - systematics, Phytopathology and Pharmacology. Buchanan, P.K.; Hseu, R.S. \& Moncalvo, J.M. (eds). Proceedings of contributed symposium 59A, B, The 5th International Mycological Congress. Vancouver, pp. 19-24.

Chang ST. 1995 - Ganoderma - The leader in production and technology of mushroom neutraceuticals. In: Proceedings of the 6th International Symposium. Recent Advances in Ganoderma lucidum Research. Kim, B.K., Kim, I.H., \& Kim, Y.S. (eds). Pharmaceutical Society of Korea Press, Seoul, pp. 43-52.

Chen AW. 2004 - Growing Ganoderma Mushroom. Mushroom Growers Handbook 1. MushWorld-Heineart Inc. Haeng-oon Bldg. 150-5 Pyungchang-dong, Jongno-gu. Part III Chapter 11. Seul Korea, pp. 110-849.

El-Fallal AA. 1990 - Studies on the ecophysiology of the padi straw mushroom Volvariella volvacea (Bull.ex Fr.) Sing. Ph.D. Thesis. University of Wales.

Foroutan A, Vaidya JG. 2007 - Record of new species of Ganoderma in Maharashtra, India. Asian J. Plant Sci. 6, 913-919.

Gao Y, Tang W, Dai X, Gao H, Chen G, Ye J, Chan E, Koh HL, Li X, Zhou S. 2005 - Effects of water-soluble Ganoderma lucidum polysaccharides on the immune functions of patients with advanced lung cancer. J. Med. Food 8, 159-168.

Hafiz F, Begum F, Hossain AMI, Parveen S, Begum M, Nessa Z, Hossain M, Munshi JL. 2007 Cultivation of Polypore Mushroom (Ganoderma resinaceum). Bangladesh J. Sci. Ind. Res. 42(2), 115-120.

Ihayere CA, Oghenekaro AO, Osemwegie OO, Okhuoya JA. 2010 - Chemical nature of Ganoderma lucidum (Curtis) Karsten from woodlands of Edo State, Nigeria. Continental J. Biol. Sci. 3, 8-15.

Jiang Y, Wang H, Lu L, Tian GY. 2005 - Chemistry of polysaccharide Lzps-1 from Ganoderma lucidum spore and anti-tumor activity of its total polysaccharides. Yao XueXueBao 40, 347350.

Lan J, Xu JT, Wang QY, He XX. 1998 - Electrophoretic studies on esterase and peroxidase isozymes in Ganoderma sp. Chin. Pharm. J. 33, 12-14.

Lee S, Park S, Oh JW, Yang C. 1998 - Natural inhibitors for protein prenyltransferase. Planta Medica 64, 303-308.

Lee SB, Taylor JW. 1990 - Isolation of DNA from fungal mycelia and single spore in: PCR protocol. A guide to method and applications. Innis, M.A., Gelfand, D.H., Sninsky, J.J. \& White, T.J. (eds). Academic Press, San Diego, California, pp. 282-287.

Lin JM, Lin CC, Chen MF, Takada A. 1995 - Radical scavenger and antihepatotoxic activity of Ganoderma formosanum, Ganoderma lucidum and Ganoderma neojaponicum. Journal of Ethnopharrnacology 47, 33-41.

Lin ZB. 2001 - Modern Research of Ganoderma lucidum, 2nd Edn. Beijing: Beijing Medical University Press, pp. 219-283.

Magday JrJC, Bungihan ME, Dulay RMR. 2014 - Optimization of mycelial growth and cultivation of fruiting body of Philippine wild strain of Ganoderma lucidum, Current Research in 
Environmentalk \& Applied Mycology 4(2), 162-172.

Mahmoud YAG, Mohamed EHFA, AbdElzaher EHF. 2007 - Response of the higher basidiomycetic Ganoderma resinaceum to sodium chloride stress. Mycobiology 35, 124-128.

Martinez AT, Barrasa JM, Martinez MJ, Almendros G, Blanco M, Gonzalez AE. 1994 Ganoderma australe: A fungus responsible for extensive delignification of some Austral hardwoods. In: Ganoderma - systematics, Phytopathology and Pharmacology. Buchanan, P.K.; Hseu, R.S. \& Moncalvo, J.M. (eds). Proceedings of contributed symposium 59A, B, The 5th International Mycological Congress. Vancouver, pp. 67-77.

Miller RNG, Holderness M, Bridge PD, Paterson RRM, Sariah M, Hussin MZ, Hilsley EJ. 1995 A multi-disciplinary approach to the characterization of Ganoderma in oil-palm cropping systems. In: Ganoderma - systematics, phytopathology and pharmacology. Buchanan, P.K.; Hseu, R.S. \& Moncalvo, J.M. (eds). Proceedings of Contributed Symposium 59A, B, The 5th International Mycological Congress, 1994, Vancouver, pp. 57-66

Mizuno T, Wang G, Zhang J, Kawagishi H, Nishitoba T, Li J. 1995 - Reishi, Ganoderma lucidum and Ganoderma tsugae: bioactive substances and medicinal effects. Food Rev Int. 11, 151166.

Mohanty PS, Harsh NSK, Pandey A. 2011 - First report of Ganoderma resinaceum and G. weberianum from north India based on ITS sequence analysis and micromorphology. Mycosphere 2, 469-474.

Moncalvo JM, Wang HF, Hseu RS. 1995a - Phylogenetic relationships in Ganoderma inferred from the internal transcribed spacers and 25S ribosomal DNA sequences. Mycologia 87(2), 223-238.

Moncalvo JM, Wang H, Hseu R. 1995b - Gene phylogeny of the Ganoderma lucidum complex based on ribosomal DNA sequences comparison with traditional taxonomic characters. Mycological Research 99(12), 1489-1499.

Moncalvo JM, Ryvarden L. 1997 - A nomenclatural study of the Ganodermataceae Donk. Oslo, Fugiflora.

Moncalvo JM, Ryvarden L. 1998 - Nomenclature of Ganodermataceae. In synopsis Fungorum 11, $1-109$.

Nanthini AUR. 2010 - Studies on the Effect of Artificially Cultivated Ganoderma lucidum on Streptozotocin induced Diabetic rats. Ph.D thesis, Periyar University.

Nobles MK. 1948 - Studies in forest pathology VI. Identification of cultures of wood-rotting fungi. Canadian Journal of Research 26(3), 281-431.

Ofodile LN, Uma NU, Kokubun T, Grayer RJ, Ogundipe OT, Simmonds MS. 2005 Antimicrobial activity of some Ganoderma species from Nigeria. Phytother. Research 19, 310-313.

Park DS, Ryu YJ. 1996 - The genetic relationship analysis of Ganoderma spp. Using the PCRRFLP and RAPD.RDA. J. Agric. Sci. Biotechnol. 38, 251-260.

Park E, Ko G, Kim J, Sohn DH. 1997 - Antifibrotic effects of a polysaccharide extracted from Ganoderma lucidum, glycyrrhizin, and pentoxifylline in rats with cirrhosis induced by biliary obstruction. Biological \& Pharmaceutical Bulletin 20(4), 417-420.

Qi JJ, Ma RC, Chen XD, Lan J. 2003 - Analysis of genetic variation in Ganoderma lucidum after space flight. Adv. Space. Research 31, 1617-1622.

Rajapakse P, Bandaranayake EMLOK, Jayarathna NPW. 2013 - Cultivation of Ganoderma (Ganoderma lucidum) mushroom under local condition. Annals of Sri Lanka Department of Agriculture 15, 345-349

Russel R, Paterson M. 2006 - Ganoderma - A therapeutic fungal biofactory. Phytochemistry 67, 1985-2001.

Ryvarden L. 1985 - Type studies in the Polyporaceae 17: species described by W.A. Murill. Mycotaxon 23(1), 169-198.

Ryvarden L. 2000 - Studies in neotropicalpolypores 2: a preliminary key to neotropical species of Ganoderma with a laccatepileus. Mycologia 92(1), 180-191. 
Sokol S, Kaldorf M, Bothe H. 1999 - Molecular characterization and taxonomic affinities of species of the white rot fungus Ganoderma. Z. Naturforsch. 54, 314-318.

Sukarno N, Aini A, Sumaarna V, Rohaeti E, Darusman LK. 2004 - Development of Ganoderma lucidum on soft and hard wood logs and determination of organic germanium and ganoderic acid content of the fruiting body produced. Journal of Mushroom Science and Production 2(3), 157-162.

Tamura K, Dudley J, Nei M, Kumar S. 2007 - MEGA4: Molecular Evolutionary Genetics Analysis (MEGA) software version 4.0. Molecular Biology and Evolution 24, 1596-1599.

Tamura K, Nei M. 1993 - Estimation of the number of nucleotide substitutions in the control region of mitochondrial DNA in humans and chimpanzees. Molecular Biology and Evolution $10,512-526$.

Thompson JD, Higgins DG, Gibson TJ. 1994 - CLUSTAL W: Improving the sensitivity of progressive multiple sequence alignment through sequence weighting, positions-specific gap penalties and weight matrix choice. Nucl. Acids Research 22, 4673-4680.

Triratana S, Thaithatgoon S, Gawgla M. 1991 - Cultivation of Ganoderma lucidumin sawdust bags. Science and Cultivation of Edible Fungi, Maher (ed.). Balkema, Rotterdam, ISBN 90 54100214 , pp. 567-572.

Toyomasu T, Takazawa H, Zennyoji A. 1992 - Restriction fragment length polymorphisms of mitochondrial DNAs from the basidiomycetes Pleurotus species. Biosci. Biotechnol. Biochem. 56, 359-361.

Wang SZ, Bai C, Fan J, Gao Y, Yang JF, Yang YJ. 2003 - A Study on the RAPD analysis of Ganoderma lucidum and Pleurotus ostreatus protoplast fusant genome. Acta Edu. lis. Fungi $10,1-5$.

Wasser SP, Weis AL. 1999 - General description of the most important medicinal higher basidiomycetes mushroom. Int. J. Med. Mush. 1, 351-370.

White TJ, Bruns T, Lee S, Taylor JW. 1990 - Amplification and direct sequencing of fungal ribosomal RNA genes for phylogenetics. In PCR Protocols: A Guide to Methods and Applications. Innis, M.A.; Gelfand, D.H.; Sninsky, J.J. \& White, T.J. (eds). Academic Press, Inc., New York, pp. 315-322. 